\title{
10. TRANSFORMACJA CYFROWA PROCESU BADANIA SPRAWOZDAŃ FINANSOWYCH
}

\author{
(iD Edyta Kalińska \\ BDO Polska \\ edyta.kalinska@bdo.pl \\ (iD) Tomasz Gabrusewicz \\ Uniwersytet Ekonomiczny w Poznaniu \\ tomasz.gabrusewicz@ue.poznan.pl \\ https://doi.org/10.18559/978-83-8211-083-8/10
}

\section{Digital transformation of the process of auditing financial statements}

\begin{abstract}
The chapter demonstrates the digital transformation process in financial audit. Digitization improves the audit quality and increases the added value for stakeholders. The use of information is more efficient and auditors could focus on significant risks. The use of new technologies in the audit of financial statements helps to obtain more relevant audit evidence.
\end{abstract}

Keywords: audit, financial statements, auditing of financial statements, digitization, modern audit process, statutory auditor.

\subsection{Wstęp}

Drugie dziesięciolecie XXI wieku to czasy wszechobecnej transformacji cyfrowej. Nawet branże, które całościowo były postrzegane jako nowoczesne i technologiczne, podlegają tym zmianom. Nie mówimy tu o bliższej czy dalszej przyszłości, lecz o tym, co dzieje się tu i teraz. Nowe technologie zmieniają kluczowe aspekty działania przedsiębiorstw, również takich, które dostarczają produkty i usługi klasyfikowane dotąd jako „tradycyjne”. Diametralnie zmieniają się wszystkie kluczowe procesy biznesowe, począwszy od sprzedaży, a skończywszy na tak skomplikowanym zagadnieniu, jakim jest zarządzanie zasobami ludzkimi.

Pandemia COVID-19, która rozpoczęła się na przełomie lat 2019 i 2020 i zamknęła społeczeństwo $\mathrm{w}$ domach, mocno przyspieszyła proces cyfryzacji praktycznie we wszystkich sektorach gospodarki. Otoczenie we współczesnej gospodarce rynkowej nigdy nie zmieniało się tak szybko jak w czasie pandemii. W otaczającej nas rzeczywistości ,świat realny” wprawdzie spowolnił, ale wykładniczo

Sugerowane cytowanie:

Kalińska, E. i Gabrusewicz, T. (2021).Transformacja cyfrowa procesu badania sprawozdań finansowych. W: K. Perez (red.), Innowacje finansowe w gospodarce 4.0 (s. 179-197). Poznań: Wydawnictwo Uniwersytetu Ekonomicznego w Poznaniu. https://doi.org/10.18559/978-83-8211-083-8/10 
przyspieszył „świat wirtualny”. Coraz częściej mówi się już nie o transformacji, ale o rewolucji cyfrowej, która zmienia krajobraz gospodarczy na świecie (zob. również: Kołodko, 2014). Zmiany technologiczne i cyfryzacja wpływają również na sposób pracy, komunikacji, zakres zadań, jakie stawiane są przed menedżerami i pracownikami. Pojawiło się i nadal pojawia zupełnie nowe ryzyko biznesowe związane z dostępem do informacji, ilością i rodzajem danych pochodzących $\mathrm{z}$ różnych źródeł oraz z bezpieczeństwem cyfrowym.

Cechą charakterystyczną współczesnej ekonomii są nieskończone wręcz konotacje między danymi (w tym danymi sprawozdawczymi), systemami, ludźmi i niespotykana wcześniej na taką skalę wymiana informacji i doświadczeń. Inwestycje w nowe technologie są niezbędne, aby „być połączonym” i dostosować model biznesowy do nowych, cyfrowych czasów (Cellary 2021). Firmy, dotychczas zupełnie niecyfrowe, wykorzystują sztuczną inteligencję, złożone systemy informatyczne, narzędzia do selekcji i analizy danych oraz dążą do automatyzacji. Rewolucja cyfrowa wpływa na biznes nie tylko bezpośrednio, ale również pośrednio. Obserwowane zmiany mają charakter zmian kulturowych. Zmieniają się więc odbiorcy dóbr i usług, zmieniają się również ich oczekiwania.

W świecie online sukces organizacji mocno zależy od posiadania kompetencji, o których jeszcze do niedawna się nie mówiło. Te kompetencje to inteligencja cyfrowa (digital inteligence, DI) i inteligencja emocjonalna (emotional inteligence, EI). Ważne jest umiejętne, bezpieczne i sprawne wykorzystywanie nowych technologii i poruszanie się $\mathrm{w}$ świecie wirtualnym oraz empatia $\mathrm{w}$ stosunku do nowego pokolenia klientów.

Zmiany te obserwują również firmy audytorskie, biegli rewidenci i zespoły badające sprawozdania finansowe przedsiębiorstw. Nie są oni wprawdzie na co dzień w jednostkach, które badają, jednak na wszystkich etapach badania obserwują zmianę sposobu myślenia w tych organizacjach i jej wpływ na procesy, ryzyko oraz transakcje.

W zmieniającym się w szybkim tempie świecie zmienia się również rola audytorów. Biegli rewidenci i audytorzy wewnętrzni muszą się mierzyć z nowymi rodzajami ryzyka i wykorzystywać efektywnie coraz większą liczbę danych. Firmy audytorskie również muszą ewoluować w zawrotnym tempie, aby w efektywny sposób mogły przeprowadzać wysokiej jakości badania sprawozdań finansowych, oparte na właściwej identyfikacji i ocenie ryzyka, zgodne z regulacjami i standardami. Najistotniejsze aspekty zmian w procesie audytu dotyczą następujących kwestii:

- identyfikacji nowych rodzajów ryzyka oraz wykorzystania analizy i eksploracji danych do identyfikacji tego ryzyka;

- procedur badania opartych na analizie danych, eksploracji procesów wspieranych nowymi technologiami i narzędziami;

- platform do wymiany danych i komunikacji między członkami zespołu audytorskiego i klientem umożliwiających w pełni zdalne badanie sprawozdań finansowych. 
Celem tego rozdziału jest zaprezentowanie najnowszych rozwiązań w zakresie badania sprawozdań finansowych przez biegłych rewidentów w zmieniającym się, cyfrowym otoczeniu. W pierwszej części dokonano prezentacji i oceny wykorzystywanych przez biegłych rewidentów narzędzi oraz technik badania sprawozdań finansowych. Zwrócono uwagę na to, że proces cyfryzacji ma usprawnić audyt i podwyższyć jego jakość, co w konsekwencji powinno się przełożyć na korzyści dla akcjonariuszy i pozostałych interesariuszy. W dalszej kolejności poruszono problematykę ryzyka istotnego zniekształcenia. Celem działań biegłego rewidenta $\mathrm{w}$ tym obszarze jest identyfikacja i ocena ryzyka istotnego zniekształcenia sprawozdań finansowych. Biegły rewident musi zaprojektować i wdrożyć odpowiednie działania w tym zakresie (Międzynarodowy Standard Badania 315). Owe działania są wykonywane niezależnie od tego, czy zniekształcenie powstało na skutek oszustwa, czy błędu na poziomie sprawozdania finansowego. Następnie, zgodnie ze sztuką badania sprawozdań finansowych, omówiono zagadnienie pozyskania dowodów badania w zmieniającym się otoczeniu jednostki. Szczególny nacisk położono na zobrazowanie analitycznych procedur wiarygodności i innych procedur wiarygodności przeprowadzanych za pomocą analitycznych procedur audytu i ich wpływ na efektywność badania, bez pominięcia analizy możliwości wystąpienia nowych rodzajów ryzyka. Rozdział kończy analiza SWOT wykorzystania zautomatyzowanych narzędzi w badaniu sprawozdań finansowych i podsumowanie podjętych $w$ rozdziale rozważań.

\subsection{Wykorzystanie zautomatyzowanych narzędzi i technik (ATA) w badaniu sprawozdań finansowych}

W erze transformacji cyfrowej biegli rewidenci i firmy audytorskie zdają sobie sprawę, że mimo iż na bieżąco przystosowują się do nowej rzeczywistości, to nadal znajdują się na początku drogi do zmian. Jest wysoce prawdopodobne, że będzie to proces ciągły, a rozwiązania technologiczne stosowane przez firmy audytorskie będą coraz bardziej zaawansowane i holistyczne. Proces transformacji cyfrowej przebiega już w głównych firmach audytorskich (zob.: https://www. rp.pl). Tworzone są wewnętrzne narzędzia oraz zespoły, które badają możliwości wykorzystania dużych baz danych przy badaniu sprawozdań finansowych. Proces ów służy nie tylko zwiększeniu efektywności badania, ale również podnosi jakość dostarczanych interesariuszom danych na temat wartości i sytuacji finansowej jednostek.

Z założenia proces cyfryzacji ma usprawnić audyt i podwyższyć jego jakość, co w konsekwencji powinno się przełożyć na korzyści dla akcjonariuszy i pozostałych interesariuszy. Audyt z wykorzystaniem nowych, cyfrowych technik wydaje się również bardziej adekwatny. Dzieje się tak z dwóch powodów: 
- po pierwsze, za pomocą narzędzi cyfrowych do analizy dużych zbiorów danych audytor może ocenić wszystkie dane finansowe i organizacyjne badanej jednostki i nie korzystać z metod opartych na próbkowaniu;

- po drugie, cyfryzacja audytu umożliwia poprawę procesu oceny ryzyka i jakości osądów poprzez identyfikację wszystkich odchyleń w organizacji.

Ważnym skutkiem cyfryzacji audytu jest możliwość koncentracji na danych bieżących, a nie tylko na analizie i potwierdzaniu informacji historycznych. Pozwala to ocenić perspektywy i stabilność biznesu badanego przedsiębiorstwa poprzez chociażby analizę zamówień zapewniających przyszłą sprzedaż. Taka dodatkowa analiza może znacząco zredukować oportunistyczne zachowania osób zarządzających przedsiębiorstwami, wesprzeć biegłego rewidenta w ocenie założenia kontynuacji działalności i wpłynąć na podprawę ładu korporacyjnego (Manita, Elommal, Baudier i Hikkerova, 2020).

Niezależnie od zmian technologicznych firmy audytorskie są zobowiązane do przestrzegania Międzynarodowych Standardów Badania lub przepisów stanowiących ekwiwalent MSB w danym kraju. Niestety, standardy te nie precyzują, w jaki sposób nowe techniki analizy danych mogą lub powinny być wykorzystywane podczas badania sprawozdania finansowego, gdyż historycznie techniki audytu wspierane komputerowo były bardzo rzadko stosowane w dotychczasowej praktyce biegłych rewidentów.

Międzynarodowe Standardy Badania (https://www.pibr.org.pl) nie wymagają określonego procesu przeprowadzania badania. Jednak w praktyce badanie sprawozdania finansowego składa się z następujących faz:

- ustalanie zakresu badania,

- identyfikacja i ocena ryzyka,

- sporządzenie planu badania,

- pozyskiwanie dowodów badania,

- formułowanie wniosków z badania,

- raportowanie.

Proces badania jest procesem interaktywnym, w którym poszczególne etapy przenikają się wzajemnie (por. rysunek 10.1). Szczególnie istotny jest powrót z późniejszych etapów do fazy identyfikacji i oceny ryzyka, gdy na etapie pozyskiwania dowodów badania zostanie zidentyfikowane nowe ryzyko wymagające rozważenia. Natomiast niektóre takie procedury oceny i identyfikacji ryzyka, jak zdobywanie wiedzy o działalności i kontroli wewnętrznej, mogą stanowić dowody badania bądź bazę do pozyskania takich dowodów.

Procedury audytu mogą być przeprowadzane za pomocą wielu narzędzi lub technik, które dzielimy na ręczne lub zautomatyzowane (często występuje kombinacja obu podejść). Zautomatyzowane narzędzia i techniki (automated tools and 
techniques, ATA $)^{1}$ mogą być wykorzystywane na każdym etapie badania sprawozdań finansowych. Obecnie ATA z powodzeniem stosowane w procesie audytu to:

- analiza danych w audycie (audit data analytics, ADA),

- eksploracja danych (data mining) definiowana jako proces ekstrakcji odpowiednich danych z dużych zbiorów danych (big data) (data analytics tests, DAT).

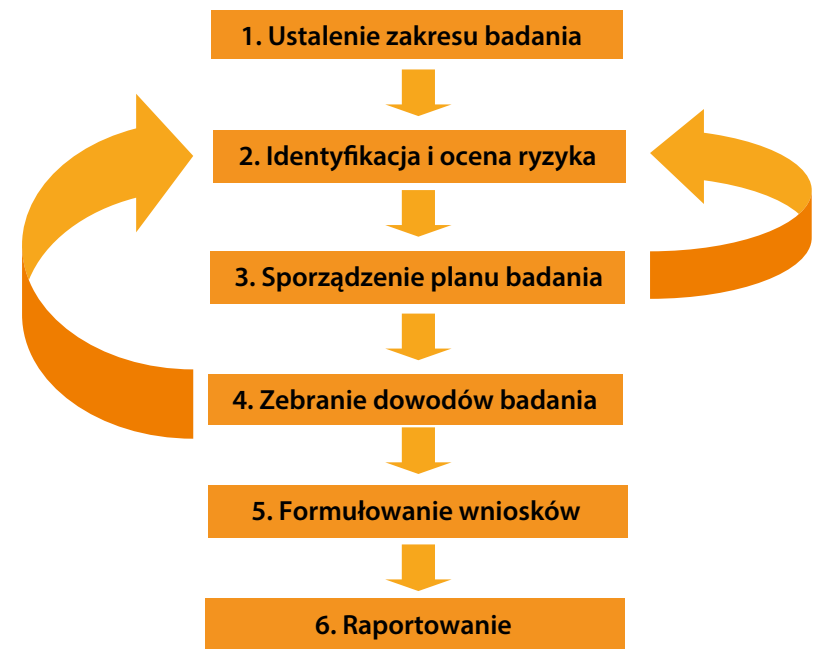

Rysunek 10.1. Etapy badania sprawozdań finansowych przedsiębiorstw według MSB

Źródło: opracowanie własne.

W celu jak najbardziej efektywnego wykorzystania powyższych technik należy je stosować już w początkowej fazie audytu, przy identyfikacji i ocenie ryzyka. Wiedza uzyskana na tym etapie przekłada się dalej na otrzymanie lepszych dowodów badania w fazie ich pozyskiwania. Biegły rewident może również wykorzystać ADA, przeprowadzając końcowy przegląd analityczny i formułując wnioski $\mathrm{z}$ badania sprawozdania finansowego.

\footnotetext{
${ }^{1}$ Specjaliści mogą w praktyce używać różnych terminów do opisywania narzędzi lub technik, które są zautomatyzowane. Na przykład stosowanie automatycznych procedur analitycznych do danych podczas procedur oceny ryzyka jest czasami określane jako analiza danych (data analytics). Jednakże termin ,analiza danych” nie został jak dotąd jednolicie zdefiniowany. Termin ten naszym zdaniem jest zbyt wąski, ponieważ nie obejmuje wszystkich pojawiających się technologii, które są obecnie wykorzystywane przy projektowaniu i wykonywaniu procedur audytu. Ponadto technologie i powiązane aplikacje audytowe wciąż ewoluują i pojawią się aplikacje związane ze sztuczną inteligencją (Artificial Intelligence, AI), do tego dojdą procesy automatyzacji oparte na robotyce i wykorzystanie dronów. Dlatego IAASB (International Auditing and Assurance Standards Board, Rada Międzynarodowych Standardów Rewizji Finansowej i Usług Atestacyjnych) używa szerszego terminu: zautomatyzowane narzędzia i techniki. W ten sam sposób czynimy w tym rozdziale.
} 
Etapy badania, na których zautomatyzowane narzędzia i techniki są najczęściej wykorzystywane, to faza identyfikacji i oceny ryzyka, w tym ryzyka oszustwa, które należy rozważyć podczas badania sprawozdania finansowego, oraz faza planowania i pozyskiwania dowodów badania. Poniżej zaprezentowano więcej szczegółów na ten temat.

\subsubsection{Zrozumienie jednostki i jej otoczenia oraz identyfikacja i ocena ryzyka istotnego zniekształcenia za pomocą ATA}

Identyfikacja i ocena ryzyka to drugi etap badania audytowego. Międzynarodowy Standard Badania 315 Identyfikacja i ocena ryzyka istotnego zniekształcenia dzięki zrozumieniu jednostki i jej otoczenia wymaga od biegłego rewidenta przeprowadzenia procedur mających na celu rozpoznanie i ocenę ryzyka istotnego zniekształcenia sprawozdania finansowego. Celem działań biegłego rewidenta jest identyfikacja i ocena tego ryzyka. Niezależnie od tego, czy zniekształcenie powstało na skutek oszustwa lub błędu na poziomie sprawozdania finansowego, czy stwierdzeń, zrozumienie jednostki i jej otoczenia, w tym kontroli wewnętrznej jednostki, stanowi podstawę do zaprojektowania i wdrożenia reakcji na ocenione ryzyko istotnego zniekształcenia (Międzynarodowy Standard Badania 315, par. 3). Standardy badania wskazują szereg procedur, które należy wykonać w celu identyfikacji ryzyka. Autorzy, kierując się profesjonalnym osądem i doświadczeniem w badaniu sprawozdań finansowych, rekomendują przeprowadzanie następujących procedur identyfikacji ryzyka:

- wstępny analityczny przegląd informacji finansowych mający na celu rozpoznanie potencjalnych rodzajów ryzyka i potwierdzenie bądź nie oczekiwań odnośnie do kształtowania się danych;

- poznanie jednostki poprzez uzyskanie stosownych informacji o jej działalności, w tym także o branży, w której ona działa, jej rynkach i otoczeniu zewnętrznym, przyjętym modelu biznesowym, źródłach finansowania;

- poznanie systemu kontroli wewnętrznej z uwzględnieniem środowiska kontroli, procesu oceny ryzyka dokonywanej przez jednostkę, systemu informatycznego i ogólnych kontroli informatycznych oraz monitorowania mechanizmów kontrolnych.

W zrozumieniu sytuacji gospodarczej, w jakiej znajduje się badana jednostka, mogą pomóc narzędzia i techniki analityczne służące rozpoznaniu i ocenie ryzyka (risk assesment data analytics, RADA). Na przykład biegły rewident może uzyskać bezpośredni dostęp do baz danych badanej jednostki wraz z ewidencją wszystkich zapisów księgowych i transakcji lub dokonać odpowiednich transferów do własnych systemów. W wyniku analizy pełnych danych oraz przy wykorzystaniu narzędzi informatycznych mogą być zidentyfikowane wszystkie odchylenia 
i anomalia, które przełożą się na ryzyko istotnego zniekształcenia i będą podlegać dalszemu badaniu i potwierdzeniom. Mogą również zostać zidentyfikowane główne źródła przychodów. Wykorzystując RADA, przeprowadzający procedury oceny ryzyka biegły rewident może korzystać z ogromnej ilości informacji nie tylko wewnętrznych, ale również zewnętrznych.

Obecnie większość informacji w środowisku biznesowym jest dostępna elektronicznie. Dzięki zaawansowanym narzędziom może ona podlegać przetwarzaniu, selekcji i analizie i pomóc w budowaniu oczekiwań przy przeprowadzaniu wstępnego przeglądu analitycznego. Zautomatyzowane narzędzia i techniki mogą wesprzeć biegłego rewidenta w zrozumieniu, jaki jest przepływ transakcji w badanej jednostce, jak wygląda struktura organizacyjna, jak przetwarzane są dane w systemach informatycznych, by mógł lepiej ocenić środowisko kontroli.

Eksploracja danych dostarcza biegłemu rewidentowi informacji o tym, w jaki sposób procesy biznesowe w badanej jednostce są powiązane $\mathrm{z}$ jej księgami rachunkowymi. Działanie to umożliwia dokonanie wstępnej oceny rodzajów ryzyka $\mathrm{z}$ wykorzystaniem procedur analitycznych $\mathrm{w}$ celu ustalenia wstępnej strategii badania oraz pomaga w ocenie, jakiego zaangażowania będzie wymagało zlecenie. Związek między procesami zachodzącymi w przedsiębiorstwie a określonymi kontami księgowymi można wizualizować i analizować ilościowo, aby zrozumieć, w jaki sposób transakcje składają się na bilans i rachunek zysków i strat. Można również dokonywać uzgodnień między procesami a zapisami w księgach rachunkowych. Każdy eksplorowany proces składa się na zestaw transakcji, które zostały zarejestrowane w systemie księgowym. Łączną wartość transakcji można porównać z danymi w sprawozdaniach finansowych. Daje to zapewnienie o kompletności i dokładności danych, co powoduje, że procedura ta jest nie tylko procedurą oceny ryzyka, ale również procedurą dostarczającą dowody badania. Podczas gdy inne techniki analizy danych są przydatne do analizy sald kont sprawozdania finansowego, eksploracja procesów może pomóc w zrozumieniu, w jaki sposób działa biznes i procesy (Werner, Wiese i Maas, 2021).

Przykłady wykorzystania RADA przy procedurach rozpoznania i oceny ryzyka istotnego zniekształcenia sprawozdania finansowego zaprezentowano $\mathrm{w}$ tabeli 10.1.

$\mathrm{Na}$ zakończenie tej części warto zauważyć, że zgodnie z Międzynarodowym Standardem Badania 200 Ogólne cele niezależnego biegłego rewidenta oraz przeprowadzanie badania zgodnie z Międzynarodowymi Standardami Badania wymagane jest, aby biegły rewident zaplanował i przeprowadził badanie z zawodowym sceptycyzmem, uznając, że mogą istnieć okoliczności powodujące istotne zniekształcenie sprawozdania finansowego. Zawodowy sceptycyzm jest niezwykle ważnym elementem badania sprawozdania finansowego. To postawa cechująca się dociekliwością, wyczuleniem na warunki mogące wskazywać na możliwe zniekształcenie spowodowane błędem lub oszustwem oraz krytycyzmem przy ocenie dowodów badania (Międzynarodowy Standard Badania 200, par. 131). 
Tabela 10.1. Wykorzystanie RADA w procedurze rozpoznania i oceny ryzyka istotnego zniekształcenia sprawozdania finansowego

\begin{tabular}{|c|c|c|c|}
\hline Procedura & $\begin{array}{c}\text { Potencjalna korzyść } \\
\text { z wykorzystania } \\
\text { RADA }\end{array}$ & Przykład wykorzystania & Wpływ na badanie \\
\hline $\begin{array}{l}\text { Wstępny } \\
\text { przegląd } \\
\text { analityczny }\end{array}$ & $\begin{array}{l}\text { RADA może pomóc } \\
\text { w przeprowadzeniu } \\
\text { dokładniejszego lub } \\
\text { bardziej szczegó- } \\
\text { łowego wstępnego } \\
\text { przeglądu analitycz- } \\
\text { nego w celu lepszej } \\
\text { identyfikacji wła- } \\
\text { ściwego ryzyka niż } \\
\text { w przypadku proce- } \\
\text { dury manualnej }\end{array}$ & $\begin{array}{l}\text { Na podstawie przeglądu ana- } \\
\text { litycznego stwierdzamy, że } \\
\text { należności są znacząco wyższe } \\
\text { niż w ubiegłym roku. Od spółki } \\
\text { możemy otrzymać bardzo ogól- } \\
\text { ne wyjaśnienia, co spowoduje } \\
\text { powstanie ryzyka związanego } \\
\text { z wyceną i istnieniem należ- } \\
\text { ności. Zastosowanie ADA po- } \\
\text { równujące należności według } \\
\text { miesięcy i klienta może wska- } \\
\text { zać, że wzrost jest związany } \\
\text { przede wszystkim ze sprzedażą } \\
\text { w ostatnim miesiącu za pośred- } \\
\text { nictwem nowego dystrybutora, } \\
\text { z którym współpracę podjęto } \\
\text { w ostatnim kwartale }\end{array}$ & $\begin{array}{l}\text { Ryzyko będzie się } \\
\text { odnosić do transakcji } \\
\text { z nowym dystrybuto- } \\
\text { rem i to te transakcje } \\
\text { będą badane, co } \\
\text { zredukuje ilość pracy } \\
\text { opartej na próbkowa- } \\
\text { niu i zakres procedur }\end{array}$ \\
\hline $\begin{array}{l}\text { Rozpoznanie } \\
\text { systemów } \\
\text { i procesów }\end{array}$ & $\begin{array}{l}\text { RADA może wes- } \\
\text { przeć biegłego } \\
\text { rewidenta w identy- } \\
\text { fikacji istotnych klas } \\
\text { transakcji }\end{array}$ & $\begin{array}{l}\text { Sortowanie transakcji zakupo- } \\
\text { wych za rok według dostawcy } \\
\text { i typów księgowań może wska- } \\
\text { zywać na obecność zakupów } \\
\text { ze spółek grupy, transakcji } \\
\text { z podmiotami powiązanymi lub } \\
\text { transakcji, które podlegają in- } \\
\text { nym procesom w odniesieniu do } \\
\text { sprawozdawczości finansowej } \\
\text { niż w przypadku standardowych } \\
\text { transakcji }\end{array}$ & $\begin{array}{l}\text { Identyfikacja szcze- } \\
\text { gółowego ryzyka } \\
\text { w odniesieniu do } \\
\text { konkretnych trans- } \\
\text { akcji, w tym ryzyka } \\
\text { oszustwa }\end{array}$ \\
\hline $\begin{array}{l}\text { Ocena syste- } \\
\text { mu kontroli }\end{array}$ & $\begin{array}{l}\text { Oprócz ogólnej } \\
\text { oceny środowiska } \\
\text { kontroli RADA może } \\
\text { wesprzeć w procesie } \\
\text { oceny zaplanowania } \\
\text { i wdrożenia kontroli }\end{array}$ & $\begin{array}{l}\text { Techniki i narzędzia zauto- } \\
\text { matyzowane mogą pokazać, } \\
\text { z jakich źródeł dane związane } \\
\text { z poszczególnymi procesami są } \\
\text { przenoszone do księgi głównej. } \\
\text { W wyniku takiej procedury } \\
\text { mogą zostać zidentyfikowane } \\
\text { niewłaściwe lub niekompletne } \\
\text { źródła }\end{array}$ & $\begin{array}{l}\text { Zidentyfikowanie } \\
\text { kontroli, które nie są } \\
\text { właściwie zaprojek- } \\
\text { towane i wdrożone. } \\
\text { W ten sposób identy- } \\
\text { fikowane są rodzaje } \\
\text { ryzyka kontroli, rów- } \\
\text { nież ryzyko oszustwa } \\
\text { związane z brakiem } \\
\text { właściwych kontroli }\end{array}$ \\
\hline
\end{tabular}

Źródło: opracowanie własne. 
Łatwiej jest zachować zawodowy sceptycyzm, gdy ma się szeroki dostęp do różnych informacji i źródeł danych. Wraz z postępem technologii, automatyzacją narzędzi wykorzystywanych do wykonywania procedur badania oraz dostępem do większej ilości informacji z szerokiego wachlarza danych z różnych źródeł zdolność biegłego rewidenta do krytycznej oceny dowodów badania zebranych podczas identyfikacji i oceny ryzyka istotnego powinna rosnąć.

\subsubsection{Planowanie i pozyskiwanie dowodów badania}

Na podstawie dokonanej w drugiej fazie badania oceny ryzyka biegły rewident projektuje strategię i plan badania, które stanowią odpowiedź audytową na zidentyfikowane ryzyko istotnego zniekształcenia sprawozdania finansowego. Zaprojektowane procedury powinny pozwolić na uzyskanie wystarczających i odpowiednich dowodów badania, stanowiących podstawę wydania opinii.

W trzeciej fazie badania sprawozdania finansowego biegły rewident tworzy szczegółowy plan badania, który jest następnie realizowany w czwartej fazie polegającej na wykonaniu zaplanowanych procedur, na którym to etapie zespół badający pozyskuje dowody badania. Zgodnie z Międzynarodowym Standardem Badania 500 Dowody badania (Międzynarodowy Standard Badania 500, par. 6) biegły rewident projektuje i przeprowadza procedury badania, które w danych okolicznościach są odpowiednie do uzyskania wystarczających i odpowiednich dowodów badania. Biegły rewident, planując badanie, łączy następujące procedury, których kombinacja ma pozwolić na otrzymanie odpowiedniego zapewnienia:

- testy systemu kontroli wewnętrznej,

- analityczne procedury wiarygodności,

- inne procedury wiarygodności.

Testy kontroli są przeprowadzane poprzez obserwację działań kontrolnych, kontrolę takich dokumentów źródłowych, jak zatwierdzone zamówienia zakupu, ponowne przeprowadzenie kontroli, lub poprzez zastosowanie procedur analitycznych. Analityczne procedury wiarygodności mogą obejmować porównanie informacji księgowych i takich wskaźników jak rotacja zapasów czy wzrost marży. Inne procedury wiarygodności polegają głównie na sprawdzeniu dokumentacji stanowiącej podstawę ujęcia księgowego transakcji. Rozumiejąc audytowaną jednostkę, jej procesy biznesowe i system kontroli wewnętrznej, audytor decyduje, który rodzaj testów jest najbardziej odpowiedni do uzyskania wystarczających i odpowiednich dowodów badania.

Przy badaniu sprawozdania finansowego w sposób tradycyjny wykorzystywane jest próbkowanie. Na podstawie próby wyciągane są wnioski na temat całej populacji transakcji. 
W erze wszechobecnej cyfryzacji bardzo zwiększyła się liczba danych, które trudno przeanalizować manualnie. Coraz więcej danych, raportów, a nawet dowodów kontroli wewnętrznej pochodzi ze zintegrowanych systemów informatycznych. Wiele kontroli to kontrole automatyczne, niepozostawiające łatwego do prześledzenia śladu rewizyjnego ${ }^{2}$. Powoduje to konieczność wykorzystywania zautomatyzowanych technik i narzędzi, gdyż przeprowadzenie badania w sposób tradycyjny może nie dostarczyć właściwych i odpowiednich dowodów badania albo być wysoce nieefektywne i czasochłonne. Zastosowanie ADA i eksploracji danych przy pozyskiwaniu dowodów badania pozwala na efektywne wykorzystanie ogromnej ilości informacji i zapewnia wysoką jakość badania poprzez kompleksowy wgląd w działalność klienta.

Obecnie przedsiębiorstwa dysponują ogromnymi wolumenami danych pochodzącymi z różnych źródeł zarówno wewnętrznych, jak i zewnętrznych. Zgromadzenie danych na temat kondycji firmy, jej perspektyw na przyszłość czy uwarunkowań rynkowych jest coraz prostsze. Wyzwanie stanowi umiejętność ich selekcji, analiza współzależności i powiązań, często nieoczywistych oraz wyciągnięcie wniosków. W wielu przypadkach właściwa analiza nie będzie wykonalna bez wykorzystania odpowiednich zautomatyzowanych technologii i technik.

Planując i przeprowadzając badanie przy wykorzystaniu nowych technologii, biegły rewident stosuje analogiczną metodologię jak przy badaniu tradycyjnym. Aby uzyskać zapewnienie, tworzy plan badania stanowiący kombinację testów kontroli, innych procedur wiarygodności i analitycznych procedur wiarygodności, jednak procedury te są wykonywane za pomocą nowych technik i narzędzi (data analytics tests, DAT). Warte podkreślenia jest to, że przy wykorzystaniu zautomatyzowanych technik i narzędzi jeszcze większej wagi niż przy tradycyjnym audycie nabiera jakość i wiarygodność danych. Podczas wykonywania DAT dane z systemu jednostki, które są wykorzystywane do wykonania testów dotyczących wszystkich istotnych kont, powinny być poddawane określonym procedurom badania w odniesieniu do ich jakości i wiarygodności.

Eksploracja procesów może wspierać biegłych rewidentów w ocenie, czy system kontroli wewnętrznej został wdrożony prawidłowo i czy można na nim polegać w konkretnym procesie biznesowym. Korzystając z tych technik, biegły rewident może ocenić, czy kontrole wewnętrzne zostały odpowiednio zaprojektowane. Ocena działania skuteczności kontroli wewnętrznych jest konieczna, aby uzyskać zapewnienie, że rzeczywiście działały one właściwie w trakcie odpowiednich okresów sprawozdawczych. Dzięki eksploracji danych biegły rewident może szczegółowo zbadać te warianty procesu, które odnoszą się do istotnych transakcji.

\footnotetext{
${ }^{2}$ Zdaniem autorów przez pojęcie „ślad rewizyjny” należy rozumieć zestawienie, które prezentuje dane z zakresu tworzenia, edycji, usuwania i księgowania dokumentów księgowych przez wszystkich użytkowników z dokładnym wyszczególnieniem daty, godziny i loginu użytkownika.
} 
Atrybuty danych dla każdego indywidualnie zarejestrowanego zdarzenia można przeanalizować, aby określić, co było wykonane, przez kogo i kiedy. Można również zidentyfikować przypadki, w których istotna czynność kontrolna nie została wykonana zgodnie z procedurą, i uzyskać wyjaśnienia do zidentyfikowanych wyjątków. Dzięki eksploracji danych biegły rewident może również sprawdzić efektywność kontroli, które nie są wbudowane w proces i nie są rejestrowane jako osobne zdarzenia, ale można je ocenić, analizując odpowiednie wartości danych transakcyjnych. Przykładem takiej kontroli może być zapewnienie systemowe zgodności ilości i cen towarów, które zostały zamówione, dostarczone i zafakturowane. Na podstawie analizy danych otrzymanych w procesie eksploracji można w prosty sposób sprawdzić, czy zgodność istnieje, bez konieczności manualnej analizy dokumentów bądź angażowania specjalisty IT, aby sprawdził, czy taka kontrola jest zaimplementowana w systemie (Werner i in., 2021).

Manualne testowanie efektywności kontroli zwykle wymaga dużego nakładu pracy i wiedzy specjalistycznej. Obecnie nie jest to już potrzebne do uzyskania zapewnienia na tym samym poziomie. Wykorzystanie eksploracji procesów to olbrzymia oszczędność czasu i zasobów wykorzystywanych w procesie badania sprawozdań finansowych. Badaniu podlega cała populacja transakcji, co pozwala na odejście od tradycyjnego badania opartego na próbkowaniu.

Nowatorska analiza danych umożliwia objęcie badaniem wszystkich istotnych transakcji w inteligentny i zautomatyzowany sposób. Ponieważ zapewnienie, które można uzyskać z testów kontroli, jest zwykle wysokie, biegli rewidenci mogą ograniczyć inne procedury, które również mogą być oparte na nowych technologiach.

W tabeli 10.2 zaprezentowano przykłady analitycznych procedur wiarygodności i innych procedur wiarygodności przeprowadzanych za pomocą DAT.

Tabela 10.2. Wykorzystanie DAT w analitycznych procedurach wiarygodności

\begin{tabular}{|l|l|l|l|}
\hline $\begin{array}{l}\text { Rodzaj } \\
\text { procedury }\end{array}$ & \multicolumn{1}{|c|}{ Scenariusz } & $\begin{array}{c}\text { Uzyskane } \\
\text { zapewnienie } \\
\text { i wplyw } \\
\text { na badanie }\end{array}$ & $\begin{array}{l}\text { Sprawdzenie wiary- } \\
\text { godności danych }\end{array}$ \\
\hline $\begin{array}{l}\text { DAT, któ- } \\
\text { ry przypo- } \\
\text { mina inną } \\
\text { procedurę } \\
\text { wiarygod- } \\
\text { ności }\end{array}$ & $\begin{array}{l}\text { Audytor używa narzędzia IT, aby } \\
\text { dopasować raport faktur sprzedaży do } \\
\text { raportu dokumentów wysyłkowych, } \\
\text { stosując numer wysyłki jako kryte- } \\
\text { rium dopasowania. Z opisu systemu } \\
\text { wynika, że dokumenty wysyłkowe są } \\
\text { tworzone przez inny system na pod- } \\
\text { stawie skanowania towarów wycho- } \\
\text { dzących z magazynu }\end{array}$ & $\begin{array}{l}\text { Procedura po- } \\
\text { legająca na } \\
\text { automatycznym } \\
\text { uzgodnieniu } \\
\text { wszystkich faktur } \\
\text { z dokumentem } \\
\text { wysyłki może } \\
\text { być uznana za } \\
\text { dowód badania } \\
\text { potwierdzający } \\
\text { istnienie }\end{array}$ & $\begin{array}{l}\text { Aby polegać na tych } \\
\text { raportach należy przete- } \\
\text { stować ogólne kontrole } \\
\text { informatyczne w obu } \\
\text { systemach, w szcze- } \\
\text { gólności kontrole } \\
\text { aplikacyjne i kontrole } \\
\text { dostępów do systemu. } \\
\text { Alternatywnie można } \\
\text { nadzorować proces ge- } \\
\text { nerowania raportów }\end{array}$ \\
\hline
\end{tabular}


Tabela $10.2-$ cd.

\begin{tabular}{|c|c|c|c|}
\hline $\begin{array}{c}\text { Rodzaj } \\
\text { procedury }\end{array}$ & Scenariusz & $\begin{array}{c}\text { Uzyskane } \\
\text { zapewnienie } \\
\text { i wplyw } \\
\text { na badanie }\end{array}$ & $\begin{array}{l}\text { Sprawdzenie wiary- } \\
\text { godności danych }\end{array}$ \\
\hline & & $\begin{array}{l}\text { i kompletność } \\
\text { sprzedaży. } \\
\text { Aby procedura } \\
\text { mogła dawać za- } \\
\text { pewnienie należy } \\
\text { się upewnić, że } \\
\text { otrzymane dane } \\
\text { są wiarygodne. } \\
\text { Zastosowanie } \\
\text { DAT zwiększy } \\
\text { efektywność } \\
\text { audytu. Biegły } \\
\text { rewident będzie } \\
\text { mógł uniknąć } \\
\text { badania na próbie }\end{array}$ & $\begin{array}{l}\text { i dodatkowo na próbie } \\
\text { przetestować, czy dane } \\
\text { w raportach są zgodne } \\
\text { z dokumentami wysył- } \\
\text { kowymi i fakturami. } \\
\text { Należy pamiętać, że } \\
\text { nie trzeba łączyć faktur } \\
\text { i dokumentów wysyłko- } \\
\text { wych, gdyż DAT wyko- } \\
\text { nuje taką czynność dla } \\
\text { całej populacji }\end{array}$ \\
\hline $\begin{array}{l}\text { DAT, } \\
\text { który } \\
\text { przypomi- } \\
\text { na ana- } \\
\text { lityczną } \\
\text { procedurę } \\
\text { wiarygod- } \\
\text { ności }\end{array}$ & $\begin{array}{l}\text { DAT będzie użyty to określenia ocze- } \\
\text { kiwań dotyczących wielkości przy- } \\
\text { chodów wykazanych w sprawozdaniu } \\
\text { finansowym w firmie zajmującej się } \\
\text { wynajmem ciężarówek. Porównujemy } \\
\text { liczbę zakontraktowanych dni wy- } \\
\text { najmu z wielkością przychodów po } \\
\text { miesiącach. } \\
\text { Etap } 1 \text {. Widzimy ścisłą zależność } \\
\text { oprócz miesiąca lipca i sierpnia. } \\
\text { Etap 2. Prosimy o wyjaśnienie i uzy- } \\
\text { skujemy informację, że zwykle dzień } \\
\text { wynajmu ma stałą cenę } 100 \text { zł, jednak } \\
\text { ze względu na okres wakacyjny cena } \\
\text { została obniżona w tych dwóch mie- } \\
\text { siącach o } 15-20 \% \text {. } \\
\text { Etap 3. Na podstawie uzyskanych } \\
\text { informacji budujemy oczekiwanie, że } \\
\text { przychody będą zgodne z liczbą dni } \\
\text { wynajmu pomnożoną przez } 100 \text { zł } \\
\text { w miesiącach wrzesień - czerwiec } \\
\text { zaś w miesiącach lipiec - sierpień do } \\
\text { zbudowania oczekiwań należy zasto- } \\
\text { sować stawkę dzienną } 80 \text { zł. } \\
\text { Etap } 4 \text {. Ustalamy akceptowalne od- } \\
\text { chylenie i wyjaśniamy odchylenia od } \\
\text { oczekiwań powyżej tego poziomu }\end{array}$ & $\begin{array}{l}\text { Taka procedu- } \\
\text { ra analityczna } \\
\text { będzie dawała } \\
\text { poziom zapew- } \\
\text { nienia uzależnio- } \\
\text { ny, podobnie jak } \\
\text { w standardowej } \\
\text { analitycznej } \\
\text { procedurze wia- } \\
\text { rygodności, od } \\
\text { źródła analizo- } \\
\text { wanych danych } \\
\text { oraz poziomu } \\
\text { akceptowalnego } \\
\text { odchylenia }\end{array}$ & $\begin{array}{l}\text { Sprawdzanie wia- } \\
\text { rygodności danych } \\
\text { użytych do tej pro- } \\
\text { cedury przebiega tak } \\
\text { samo jak w przypadku } \\
\text { tradycyjnej procedu- } \\
\text { ry analitycznej. Przy } \\
\text { teście opieramy się } \\
\text { na raporcie sprzedaży } \\
\text { po miesiącach oraz } \\
\text { raporcie pokazującym } \\
\text { liczbę dni wynajmu. } \\
\text { Miesięczna sprzedaż } \\
\text { jest wpisywana do księ- } \\
\text { gi głównej. Możemy na } \\
\text { próbie sprawdzić, czy } \\
\text { dokumenty sprzedaży } \\
\text { są ujęte prawidłowo. } \\
\text { Alternatywnie możemy } \\
\text { w strategii badania ująć } \\
\text { testy kontroli nad rapor- } \\
\text { towaniem sprzedaży }\end{array}$ \\
\hline
\end{tabular}

Źródło: opracowanie własne. 
Korzystanie ze zautomatyzowanych narzędzi i technik badania z pewnością może podnieść jakość i efektywność badania, jednak wiąże się z nim również nowe ryzyko. Wykorzystanie technologii może (potencjalnie) powodować stronniczość biegłego rewidenta lub ogólne ryzyko nadmiernego polegania na informacjach lub wynikach przeprowadzonej procedury badania. Nadmierne poleganie na tak generowanych informacjach może przybierać różne formy, takie jak niezrozumienie, jak działa nowe narzędzie, bądź poleganie na systemach i danych badanego podmiotu bez dodatkowych testów (Non- authoritative support material related to technology: Frequently asked question (FAQ) addressing, s. 2). Na przykład biegły rewident może mieć skłonność, aby bardziej wierzyć informacjom uzyskanym ze zautomatyzowanych narzędzi niż informacjom uzyskanym z innych źródeł, nawet wtedy, gdy te pierwsze są niespójne i powinny budzić wątpliwości.

Dlatego właśnie pisząc o transformacji cyfrowej w procesie badania sprawozdań, nie możemy zapomnieć o rosnącym ryzyku zbyt dużego polegania na nowych technologiach i narzędziach. Bardzo ważne jest, aby firmy audytorskie, zmieniając swoje procedury i standardy, a w konsekwencji implementując nowe narzędzia do przeprowadzania procesu badania sprawozdań finansowych, nie zapomniały o odpowiednich szkoleniach i budzeniu świadomości, że wraz z nowymi technologiami pojawia się nowe ryzyko.

Kluczem do kreacji nowoczesnego procesu badania sprawozdań finansowych jest inteligencja emocjonalna powiązana $z$ inteligencją cyfrową. Biegły rewident przyszłości musi podołać tym zmianom.

\subsection{Zdalne badanie sprawozdań finansowych}

Większość firm audytorskich od wielu lat podejmowała próby wdrożenia rozwiązań, które umożliwiałyby przeprowadzanie prac audytorskich zdalnie, bez dłuższych wizyt u klientów. Wykorzystywały przy tym dostępne odpłatnie i nieodpłatnie platformy do wymiany danych. Wiele firm audytorskich, chcąc w pełni zadbać o bezpieczeństwo danych klienta, stworzyło własne rozwiązania pozwalające na dwustronną wymianę danych i śledzenie postępów badania sprawozdania finansowego, zarówno przez kierujących badaniem, jak i klienta.

Praca zdalna i wykorzystanie portali do wymiany danych automatyzują, centralizują i standaryzują proces audytu w zakresie rutynowych działań wymaganych przez standardy badania. Opisany proces pozwala na niezwykłe jak dotąd oszczędności czasu, który można wykorzystać do lepszej identyfikacji i oceny ryzyka istotnego zniekształcenia sprawozdań finansowych, jak również większego zaangażowania w badanie niestandardowych i złożonych transakcji.

Proces zdalnego badania sprawozdania finansowego zwykle przebiega w następujący sposób: 
- wgranie struktury dokumentów, które należy przygotować do badania, na odpowiednią platformę, wraz ze wskazaniem terminów dostarczenia;

- zamieszczanie dokumentacji elektronicznej na platformie przez klienta;

- sprawdzanie zamieszczonych danych przez zespoły audytorskie i dodawanie dodatkowych zapytań;

- potwierdzanie zamieszczania i odbierania dokumentów przez uczestniczących w procesie.

Wiele platform do wymiany danych daje badanym przedsiębiorstwom dostęp do bazy wiedzy firmy audytorskiej. Są to wzory sprawozdań, listy kontrolne i inne istotne materiały organizacyjne i finansowe. Podczas zdalnego audytu biegły rewident coraz częściej otrzymuje dostęp do systemów klienta, aby samodzielnie generować raport lub wykonywać inne czynności audytorskie, co uwiarygadnia otrzymane dane i zapewnia ich kompletność.

Wiele firm audytorskich od dłuższego czasu próbowało przekonać klientów do tego, że badanie sprawozdania finansowego da się w dużej mierze przeprowadzić zdalnie. Jednak dopiero pandemia COVID-19 pozwoliła na wdrożenie tych rozwiązań z sukcesem. Zdalny audyt to nie tylko portale do wymiany danych, ale również spotkania online, także takie, w czasie których są przeprowadzane testy kontroli i prezentowane dokumenty, spotkania z radami nadzorczymi i komitetami audytu.

Oczywiście istnieją procedury, które bardzo trudno przeprowadzić zdalnie albo przeprowadzanie ich $\mathrm{w}$ taki sposób jest związane $\mathrm{z}$ wyższym ryzykiem istotnego zniekształcenia spowodowanego oszustwem. Za przykład może posłużyć obserwacja inwentaryzacji. Jeśli akceptujemy dowód badania będący zrzutem z systemu przygotowanym przez klienta, należy się upewnić, że nie został on zmodyfikowany. Krytycznie należy oceniać wszelkie dokumenty otrzymywane elektronicznie, gdyż znacznie łatwiej je sfałszować.

Niezwykle trudno jest zdobyć wiedzę o jednostce, zidentyfikować wszystkie rodzaje ryzyka i odpowiednio je ocenić, pracując tylko i wyłącznie zdalnie. Spotkania online mają charakter formalny, uczestniczy w nich najczęściej większe grono osób. Na tego typu spotkaniach nie uzyska się informacji, jaką można byłoby uzyskać, siedząc w jednym pokoju i rozmawiając niezależnie z pracownikami z różnych działów. Ważną techniką badania jest obserwacja. Wiedzy uzyskanej podczas wizyty w fabryce, magazynie czy laboratorium nie da się pozyskać zdalnie, siedząc przed ekranem monitora.

\subsection{Analiza SWOT wykorzystania ATA w badaniu sprawozdań finansowych}

\section{Mocne strony}

Korzystanie ze zautomatyzowanych narzędzi i technik badania wpływa pozytywnie nie tylko na jakość, ale i efektywność procesu sprawozdania finansowego. 
Mogą być one wykorzystywane na każdym etapie badania. Wykorzystanie RADA pozawala na lepszą identyfikację i ocenę ryzyka istotnego zniekształcenia. Zidentyfikowane w ten sposób ryzyko jest bardziej precyzyjne i specyficzne dla badanej jednostki. Wykorzystanie wspieranych narzędziami procedur analitycznych pozwala na ograniczenie badania na próbie i konieczności ekstrapolacji uzyskanych wyników. Procedurą może być objęta cała populacja, co wpływa na wyższe zapewnienie z tak zaplanowanego testu.

Wykorzystanie eksploracji danych i procesów może zastąpić wymagające dużego nakładu pracy manualne testowanie efektywności kontroli wewnętrznej. Nowoczesne testy kontroli nie wymagają wiedzy specjalistycznej, na przykład $\mathrm{z}$ zakresu IT. Ich przewagą jest również większa skuteczność w wykrywaniu słabości kontroli wewnętrznej, w szczególności słabości mających charakter systemowy. Również w tym przypadku testowaniu podlega cała populacja transakcji, co pozwala na odejście od tradycyjnego badania opartego na próbkowaniu.

Nowatorska analiza danych umożliwia objęcie badaniem wszystkich istotnych transakcji w inteligentny i zautomatyzowany sposób, oszczędzając czas i zasoby.

\section{Słabe strony}

Wykorzystanie nowych technologii w procesie audytu może powodować stronniczość biegłego rewidenta lub ogólne ryzyko nadmiernego polegania na informacjach lub wynikach przeprowadzonej procedury badania. Może to wynikać z niezrozumienia, jak działają nowe narzędzia, bądź z naturalnej skłonności do oceny jako bardziej wiarygodnych informacji uzyskanych z zautomatyzowanych narzędzi niż tych pozyskanych inną drogą, nawet wtedy, gdy to one są bardziej spójne.

Wykorzystanie ADA jest związane z nowymi rodzajami ryzyka, w szczególności ryzykiem modyfikacji danych, które są przekazywane do analizy. Należy więc pamiętać o zaplanowaniu odpowiednich testów służących weryfikacji otrzymanych danych. Nie można zapomnieć o tym, że nowe technologie $\mathrm{w}$ audycie są związane z koniecznością nabycia zaawansowanych narzędzi oraz zatrudnieniem pracowników z wysokimi kompetencjami cyfrowymi. W wielu przypadkach uzyskanie korzyści z cyfrowego audytu będzie wymagało dużych inwestycji ze strony firm audytorskich, nie tylko w narzędzia, ale również w szkolenia pracowników.

\section{Szanse}

Niewątpliwą szansą dla firm audytorskich, które dokonają transformacji cyfrowej procesu audytu, jest możliwość zaoferowania badanym podmiotom bardziej efektywnego i przystosowanego do ich potrzeb badania sprawozdań finansowych. Nowe technologie dają możliwość wykrycia słabości w systemach kontroli wewnętrznej, które nie byłyby do wykrycia przy zastosowaniu tradycyjnych metod 
testowania. Audyt finansowy może więc stać się dla przedsiębiorstw nie tylko obowiązkiem, ale i szansą na pozyskanie informacji wspierających prowadzenie efektywnego biznesu.

Szeroko pojęci interesariusze mogą otrzymać wyższej jakości badanie sprawozdań finansowych, lepiej dostosowane do wykrywania nie tylko błędów, ale również oszustw sprawozdawczych, a nawet innego rodzaju oszustw, na które jest narażony każdy przedsiębiorca. Rola biegłego rewidenta może dzięki temu znacząco wzrosnąć.

\section{Zagrożenia}

Nowe możliwości są nieodłącznie związane z nowymi zagrożeniami. W Międzynarodowych Standardach Badania w obecnym kształcie brak jest rozważań dotyczących nowych rodzajów testów i technologii. Cyfryzacja w audycie finansowym będzie wymagała fundamentalnych zmian w standardach, aby odpowiadały na pytania dotyczące nowych sposobów i technik badania. Wykorzystanie nowych technologii wiąże się z nowymi rodzajami ryzyka, które jeszcze nie zostały określone, a które na pewno będą musiały zostać rozważone podczas badania. Jest to ryzyko związane z przechowywaniem danych, ich bezpieczeństwem oraz ich podatnością na modyfikację. Aby procedury wspierane nowoczesnymi narzędziami były efektywne, konieczny będzie pewien zakres ich standaryzacji. Paradoksalnie może to zwiększać ryzyko oszustwa, gdy kierownictwo badanych podmiotów pozna algorytm wykonywanych testów. Może pojawić się pokusa takiej prezentacji danych, aby uniknąć wykrycia celowych zniekształceń w procesie badania. Istotną kwestią jest również dostępność pracowników posiadających odpowiednie kompetencje, aby stosować nowe narzędzia i techniki.

Tabela 10.3. Analiza SWOT analitycznych procedur wiarygodności ADA

\begin{tabular}{|c|c|}
\hline Mocne strony & Slabe strony \\
\hline $\begin{array}{l}\text { - możliwość przeprowadzenia bardziej do- } \\
\text { kładnych testów analitycznych } \\
\text { - lepszy proces identyfikacji i oceny ryzyka } \\
\text { - możliwość uzyskania wysokiego zapewnie- } \\
\text { nia z prostej procedury } \\
\text { - ograniczenie badania na próbie i konieczno- } \\
\text { ści ekstrapolacji wyników } \\
\text { - objęcie procedurą całej populacji } \\
\text { - łatwiejsza identyfikacja luk w systemach } \\
\text { kontroli wewnętrznej } \\
\text { - zastąpienie testowania kontroli automatycz- } \\
\text { nych przez drogich i trudno dostępnych eks- } \\
\text { pertów eksploracją danych }\end{array}$ & $\begin{array}{l}\text { - konieczność weryfikacji rzetelności danych } \\
\text { używanych do ADA } \\
\text { - ryzyko stronniczości biegłego rewidenta } \\
\text { (zbytnie poleganie na technologiach) } \\
\text { - ryzyko modyfikacji danych przekazanych do } \\
\text { analizy } \\
\text { - konieczność stworzenia/zakupienia odpo- } \\
\text { wiednich narzędzi informatycznych } \\
\text { - konieczność zatrudnienia pracowników } \\
\text { z kompetencjami cyfrowymi }\end{array}$ \\
\hline
\end{tabular}


Tabela $10.3-$ cd.

\begin{tabular}{|c|c|}
\hline Szanse & Zagrożenia \\
\hline $\begin{array}{l}\text { - możliwość zaoferowania klientom bardziej } \\
\text { efektywnego i przystosowanego do ich spe- } \\
\text { cyfiki badania sprawozdania finansowego } \\
\text { - wartość dodana dla badanych podmiotów } \\
\text { w postaci lepszych rekomendacji, w szcze- } \\
\text { gólności w odniesieniu do systemów kon- } \\
\text { troli wewnętrznej } \\
\text { - dostarczanie interesariuszom wyższej jako- } \\
\text { ści badania sprawozdania finansowego } \\
\text { - łatwiejsze wykrywanie oszukańczej spra- } \\
\text { wozdawczości i innych oszustw }\end{array}$ & $\begin{array}{l}\text { - konieczność aktualizacji standardów bada- } \\
\text { nia, aby uwzględniały nowe rodzaje testów } \\
\text { - nowe ryzyko związane z technologiami } \\
\text { informatycznymi } \\
\text { - ryzyko przewidywalności wykonywanych } \\
\text { procedur i zwiększone ryzyko oszustwa } \\
\text { - brak specjalistów z kompetencjami cyfrowy- } \\
\text { mi na rynku }\end{array}$ \\
\hline
\end{tabular}

Źródło: opracowanie własne.

\subsection{Podsumowanie}

Transformacja cyfrowa wymusiła na firmach audytorskich i biegłych rewidentach dostosowanie działania do nowej rzeczywistości, przy jednoczesnym przestrzeganiu obowiązujących standardów badania sprawozdań finansowych. Niezwykle istotne jest wykorzystanie nowych technologii, jednak równie ważne jest dostarczanie sprawozdań finansowych wysokiej jakości, przeprowadzanie badań zgodnie z Międzynarodowymi Standardami Badania lub innymi, obowiązującymi w danym kraju standardami badania sprawozdań finansowych.

Automatyzacja rutynowych czynności i zaawansowane narzędzia do analizy danych mogą pomóc audytorom finansowym koncentrować się na najważniejszym aspekcie audytu, czyli na identyfikacji różnych rodzajów ryzyka, w tym biznesowego, które znajdują odzwierciedlenie w ryzyku zniekształcenia sprawozdań finansowych. Jeśli uda się owe zmiany przeprowadzić we właściwy sposób, komunikacja z interesariuszami i transparentność raportowania poprawią się, co przełoży się na korzyści dla interesariuszy. Komitety audytu i inne osoby sprawujące nadzór otrzymają lepszą informację o ryzyku i szansach biznesowych. Zmiana w sposobie wykonywania procedur badania, wykorzystanie automatyzacji i pogłębionych analiz nie tylko czyni audyt finansowy bardziej efektywnym, ale pozwala też lepiej poznać biznes i zwrócić uwagę na właściwe rodzaje ryzyka.

Nowe technologie sprawiają, że biegły rewident dysponuje obecnie ogromną ilością informacji o jednostce i danych pochodzących ze spółki i otoczenia. Łatwiej mu pozostawać $\mathrm{w}$ kontakcie $\mathrm{z}$ interesariuszami, co zwiększa zaufanie do sprawozdawczości finansowej oraz pozwala na uzyskanie wartości dodanej ze standardowego badania sprawozdania finansowego. 
Transformacja cyfrowa w audycie to nie odległa przyszłość, to rzeczywistość. Audyt finansowy w nowym wydaniu wspiera funkcjonowanie przedsiębiorstw w zmienionym świecie. Jego celem jest zapewnienie interesariuszy o tym, że badane jednostki dobrze funkcjonują w nowych okolicznościach. Rosnąca ilość informacji zbieranych przez przedsiębiorstwa (dzięki transformacji cyfrowej procesu badania) jest efektywnie wykorzystana, aby zapewnić wysoką jakość badania i pozwolić audytorom położyć większy nacisk na identyfikację ryzyka i wgląd w działalność firmy. Ilość i niewykorzystany potencjał danych generowanych przez nowe technologie napędza potrzebę ciągłej cyfryzacji audytu. Firmy audytorskie w nowej cyfrowej rzeczywistości powinny (Manita i in., 2020):

- stosować odpowiednie technologie i inwestować w szkolenie swoich pracowników i współpracowników;

- automatyzować rutynowe procesy;

- w nowy sposób zorganizować zespoły audytowe i nadać ich członkom nowe role z uwzględnieniem procesów, które są zautomatyzowane;

- zainwestować w nowe narzędzia;

- stworzyć kulturę innowacji na wszystkich poziomach, aby nie przeoczyć trendów rynkowych i zmian w modelach biznesów;

- dbać o bezpieczeństwo transferów danych i właściwe pozyskiwanie danych;

- stworzyć nową politykę rekrutacyjną skupiającą się na umiejętnościach cyfrowych i innowacyjności.

Transformacja cyfrowa w procesie badania sprawozdań finansowych, która stała się faktem, pokazała, że standardy badania w obecnym kształcie nie do końca odpowiadają procesowi współczesnego audytu. Rada Międzynarodowych Standardów Rewizji Finansowej i Usług Atestacyjnych i podobne instytucje powinny rozważyć ich aktualizację i zawarcie w tych standardach szczegółowych regulacji dotyczących wykorzystania nowych technologii.

\section{Bibliografia}

Cellary, W. Musimy być gotowi na przemyst 4.0. Pobrane 18 czerwca $2021 \mathrm{z}$ https://alebank.pl/prof-wojciech-cellary-musimy-byc-gotowi-na-przemysl-4-0/?id=343817\&ca tid $=25926 \&$ cat $2 \mathrm{id}=25924$

https://www.pibr.org.pl/pl/krajowe-standardy-rewizji-finansowej. Pobrane 20 czerwca 2021 https://www.rp.pl/Ranking-audytorow/304089907-Ranking-audytorow-KPMG-zwyciezc a-tegorocznego-zestawienia.html. Pobrane 17 czerwca 2021.

Kołodko, G. (2014). 2025: dwie historie gospodarczego wzrostu. W: P. Kozłowski i M. Wojtysiak-Kotlarski (red.), Grzegorz W. Kołodko i ćwierćwiecze transformacji. Warszawa: WN Scholar. 
Manita, R., Elommal, N., Baudier, P. i Hikkerova L. (2020). The digital transformation of external audit and its impact on corporate governance. Technological Forecasting \& Social Change, 150, 119751.

Międzynarodowy Standard Badania 200 Ogólne cele niezależnego biegłego rewidenta oraz przeprowadzanie badania zgodnie z Międzynarodowymi Standardami Badania.

Międzynarodowy Standard Badania 315 (zmieniony).

Międzynarodowy Standard Badania 500. Dowody badania.

Non-authoritative support material related to technology: Frequently asked question (FAQ) addressing the risk of overreliance on technology-use of ATT and use of information produced by the entity's system, IASB.

Non-autoritative suport material related to technology: Frequently Asked Questions (FAQ) - the use of automated tools and techniques when identyfying and assessing risk of material misstaitment in accordance with ISA 315 (revised 2019), IASB.

Werner, M., Wiese, M. i Maas, A. (2021), Embedding process mining into financial statement audits. International Journal of Accounting Information Systems, 41, 100514. 